\title{
Sendai Virus Fusion Activity as Modulated by Target Membrane Components
}

\author{
Isabel Nunes-Correia, ${ }^{1,3}$ João Ramalho-Santos, ${ }^{2,3}$ and Maria C. Pedroso de Lima ${ }^{1,3,4}$ \\ Received January 19, 1998

\begin{abstract}
We have studied the differences between erythrocytes and erythrocyte ghosts as target membranes for the study of Sendai virus fusion activity. Fusion was monitored continuously by fluorescence dequenching of R18-labeled virus. Experiments were carried out either with or without virus/target membrane prebinding. When Sendai virus was added directly to a erythrocyte/erythrocyte ghost suspension, fusion was always lower than that obtained when experiments were carried out with virus already bound to the erythrocyte/erythrocyte ghost in the cold, since with virus prebinding fusion can be triggered more rapidly. Although virus binding to both erythrocytes and erythrocyte ghosts was similar, fusion activity was much more pronounced when erythrocyte ghosts were used as target membranes. These observations indicate that intact erythrocytes and erythrocyte ghosts are not equivalent as target membranes for the study of Sendai virus fusion activity. Fusion of Sendai virus with both target membranes was inhibited when erythrocytes or erythrocyte ghosts were pretreated with proteinase $K$, suggesting a role of target membrane proteins in this process. Treatment of both target membranes with neuraminidase, which removes sialic acid residues (the biological receptors for Sendai virus) greatly reduced viral binding. Interestingly, this treatment had no significant effect on the fusion reaction itself.
\end{abstract}

KEY WORDS: Sendai virus; erythrocytes; erythrocyte ghosts; membrane fusion; fluorescence dequenching.

ABBREVIATIONS: EGTA, Ethylene glycol-bis( $\beta$-aminoethyl ether) $N, N, N^{\prime}, N^{\prime}$-tetraacetic acid; R18-octadecylrhodamine B chloride.

\section{INTRODUCTION}

Sendai virus (hemagglutinating virus of Japan) belongs to the paramyoxovirus family, and like many other enveloped viruses, infects host cells by a membrane fusion event (Hoekstra and Kok, 1989; Hoekstra, 1990; Stegmann et al., 1989). Fusion takes place at neutral $\mathrm{pH}$ and is mediated by two viral membrane glycoproteins, one involved in virus-cell binding and one specific for fusion (Haywood and Boyer, 1982; Hoekstra et al., 1985). The protein designated $\mathrm{HN}$ has hemagglutinating and neuraminidase activities and mediates the initial virus-target membrane binding, while

${ }^{1}$ Department of Biochemistry, University of Coimbra, Apartado 3126, 3000 Coimbra, Portugal.

${ }^{2}$ Department of Zoology, University of Coimbra, 3000 Coimbra, Portugal.

${ }^{3}$ Center for Neurosciences of Coimbra, University of Coimbra, 3000 Coimbra, Portugal.

${ }^{4}$ To whom correspondence should be addressed.

59 
the fusion protein $(\mathrm{F})$ triggers the actual membrane merging (Novick and Hoekstra, 1988).

Although Sendai virus infects living cells, erythrocyte ghosts have been frequently used as target membranes in studies of viral fusion activity (Hoekstra et al., 1985; Hoekstra and Klappe, 1986; Stegmann et al., 1986). However, during the preparation of the erythrocyte ghosts several factors can modify membrane physical properties and alter the structure of membrane surface components (Schwoch and Passow, 1973) that may be involved in the fusion process. Therefore we have investigated the differences between human erythrocyte ghosts and human erythrocytes as target membranes for the study of Sendai virus fusion activity. Fusion of Sendai virus with both target membranes was monitored with the R18-fluorescence assay, which allows a sensitive and continuous monitoring of fusion between native biological membranes (Hoekstra et al., 1984; Pedroso de Lima et al., 1995).

We have also investigated the potential role of membrane proteins in the fusion process. For this purpose erythrocytes and erythrocyte ghosts were pretreated with proteinase $\mathrm{K}$, and Sendai virus fusion activity towards both treated target membranes was examined. Sialic acid residues have been recognized as membrane receptors for binding of both Sendai and influenza viruses (Haywood and Boyer, 1982; Hoekstra, 1990), and have also been shown to modulate influenza virus fusion activity (Stegmann et al., 1986). We were interested in studying the role of these residues in Sendai virus fusion activity using our experimental system. Therefore, erythrocytes and erythrocyte ghosts were treated with neuraminidase and the effect of this pretreatment on virus-target membrane binding and on the fusion process itself was assessed.

\section{MATERIALS AND METHODS}

\section{Chemicals}

Octadecylrhodamine B chloride (R18) was obtained from Molecular Probes Inc. (Eugene, OR), neuraminidase was purchased from Calbiochem (San Diego, CA) and proteinase $\mathrm{K}$ was obtained from Sigma Chemical Co. (St. Louis, MO).

\section{Virus}

Sendai virus (Hemagglutinating virus of Japan), $\mathrm{Z}$ strain, was obtained from SPAFAS Inc. (Preston, CT). The virus was grown for $72 \mathrm{~h}$ in the allantoic cavity of 10-day-old embryonated eggs, purified by differential centrifugation and stored at $-70^{\circ} \mathrm{C}$ in phosphate buffered saline (Maeda et al., 1975).

\section{Virus Labeling}

Sendai virus was labeled with octadecylrhodamine B chloride as described previously (Hoekstra et al., 1984; Ramalho-Santos et al., 1993). The final concentration of added probe corresponded to approximately 5 mole $\%$ of total viral lipid and that of ethanol was less than $1 \%(\mathrm{v} / \mathrm{v})$. The mixture was incubated in the dark for $30 \mathrm{~min}$ 
at room temperature. R18-labeled virus was separated from non inserted fluorophore by chromatography on Sephadex G-75 (Pharmacia, Uppsala, Sweden) using $10 \mathrm{mM}$ HEPES, $150 \mathrm{mM} \mathrm{NaCl}, \mathrm{pH} 7.4$ as elution buffer. The protein concentration of the labeled virus was determined by the Lowry assay.

\section{Preparation of Erythrocytes and Erythrocyte Ghosts}

Erythrocytes were obtained from freshly drawn human blood by centrifugation at $2300 \mathrm{~g}$ in a Sorvall centrifuge using the SS-34 rotor for $10 \mathrm{~min}$ at $4^{\circ} \mathrm{C}$. The erythrocyte pellet was washed three times with $5 \mathrm{mM}$ sodium phosphate, $150 \mathrm{mM} \mathrm{NaCl}$, $0.1 \%$ BSA, $\mathrm{pH} 7.4$. The erythrocytes were counted in a hemocytometer and stored at $4^{\circ} \mathrm{C}$.

Erythrocyte ghosts were prepared from freshly drawn human blood by hypotonic lysis of the erythrocytes in $5 \mathrm{mM}$ sodium phosphate, $0.1 \mathrm{mM}$ EGTA, pH 8.0 at $4^{\circ} \mathrm{C}$, essentially as described by Steck and Kant (Steck and Kant, 1974). The erythrocyte ghosts were counted in a hemocytometer and stored at $4^{\circ} \mathrm{C}$.

\section{Enzymatic Treatment}

For proteinase $\mathrm{K}$ treatment $2 \times 10^{8}$ of erythrocytes/erythrocyte ghosts were incubated for $30 \mathrm{~min}$ at $37^{\circ} \mathrm{C}$ with $700 \mu \mathrm{g}$ of proteinase $\mathrm{K}$ in $1 \mathrm{ml}$ of $5 \mathrm{mM}$ sodium phosphate, $150 \mathrm{mM} \mathrm{NaCl}, \mathrm{pH}$ 7.4. Following this incubation, the target membranes were centrifuged at $22,000 \mathrm{~g}$ in a Sorvall centrifuge using the SE-12 rotor for $10 \mathrm{~min}$ at $4^{\circ} \mathrm{C}$. The pellet was resuspended in $2 \mathrm{ml}$ of $10 \mathrm{mM}$ HEPES, $150 \mathrm{mM} \mathrm{NaCl}, \mathrm{pH} 7.4$ and washed three more times. Neuraminidase treatment of erythrocytes/erythrocyte ghosts was carried out with 10 milliunits of Clostridium perfringens neuraminidase/ $2 \times 10^{8}$ of erythrocytes/erythrocyte ghosts in $0.5 \mathrm{ml}$ of $50 \mathrm{mM}$ sodium acetate, $154 \mathrm{mM} \mathrm{NaCl}, 4 \mathrm{mM} \mathrm{CaCl}$, pH 5.5 for $60 \mathrm{~min}$ at $37^{\circ} \mathrm{C}$. Following this incubation, the target membranes were centrifuged at $22,000 \mathrm{~g}$ in a Sorvall centrifuge using the SE- 12 rotor for $10 \mathrm{~min}$ at $4^{\circ} \mathrm{C}$. The pellet was resuspended in $2 \mathrm{ml}$ of $10 \mathrm{mM}$ HEPES, $150 \mathrm{mM} \mathrm{NaCl}, \mathrm{pH} 7.4$ and washed three more times.

\section{Fusion of R18-Labeled Sendai Virus with Erythrocytes or Erythrocyte Ghosts}

Fusion was monitored using a procedure that detects the merging of lipid bilayers. The method relies upon the relief of fluorescence self-quenching of R18. Upon fusion of R18-labeled virus with target membranes devoid of the probe, the surface density of R18 will decrease as a result of mixing the viral and target membrane components, allowing an accurate measurement of the fusion reaction (Hoekstra et al., 1984; Pedroso de Lima et al., 1992).

We used two different experimental approaches to monitor membrane merging. In one of the procedures fusion was initiated by rapid injection of R18-labeled virus into a cuvette containing the erythrocytes or erythrocyte ghosts suspension, and fusion monitored continuously as a function of R 18 dequenching. In the other experimental procedure the virus was added to the target membranes on ice in a small 
volume of buffer and incubated for $15 \mathrm{~min}$. Fusion was monitored after the virustarget membrane mixture was transferred to prewarmed buffer at $37^{\circ} \mathrm{C}$ in the fluorometer cuvette. Fusion experiments were always carried out with $2 \times 10^{8}$ of erythrocytes/erythrocyte ghosts and $10 \mu \mathrm{g}$ of Sendai virus in a final incubation volume of $2 \mathrm{ml}$.

Fluorescence measurements were performed in a Spex Fluorolog fluorometer with excitation at $560 \mathrm{~nm}$ and emission at $590 \mathrm{~nm}$, using the front-face configuration in the emission channel and a filter at the emission monochromator, in order to reduce the contribution of light scattering. The sample chamber was equipped with a magnetic stirring device, and the temperature was controlled with a thermostatted circulating water bath. The fluorescence scale was calibrated such that the initial fluorescence of R18-labeled virus and erythrocytes or erythrocyte ghosts was set at $0 \%$ fluorescence. The value obtained after solubilization of the virus and the target membranes at the end of each experiment with $1 \%(\mathrm{v} / \mathrm{v})$ Triton X-100, was set at $100 \%$ fluorescence.

\section{Measurement of Sendai Virus-Erythrocytes/Erythrocyte Ghosts Binding}

R18-labeled Sendai virus $(5 \mu \mathrm{g} / \mathrm{ml})$ and erythrocytes/erythrocyte ghosts $\left(1 \times 10^{8} / \mathrm{ml}\right)$, were incubated in a final volume of $2 \mathrm{ml}$ of $10 \mathrm{mM}$ HEPES, $150 \mathrm{mM}$ $\mathrm{NaCl}, \mathrm{pH} 7.4$, on ice, for $30 \mathrm{~min}$. Under these conditions fusion between Sendai virus and erythrocytes/erythrocyte ghosts is inhibited, although the aggregation process takes place. The samples were then centrifuged at $10,500 \mathrm{~g}$ for $8 \mathrm{~min}$. Upon centrifugation target membranes pellet, while unbound virions remain in the supernatant. Binding percentages were calculated from fluorescence values after addition of $1 \%(\mathrm{v} / \mathrm{v})$ Triton X-100, both for the supernatant and the pellet (resuspended in $2 \mathrm{ml}$ of buffer). Fluorescence measurements were performed as previously described.

\section{RESULTS AND DISCUSSION}

\section{Erythrocyte and Erythrocyte Ghosts as Target Membranes for the Study of Sendai Virus Fusion Activity}

Many studies concerning the fusion activity of lipid-enveloped viruses use erythrocyte ghosts as target membranes for these pathogenic agents. However during the preparation of the erythrocyte ghosts several factors can modify the structure of membrane surface. Therefore, we have tried to investigate the differences between human erythrocytes and human erythrocyte ghosts as target membranes for Sendai virus, using the R18 fluorescence dequenching assay, a reliable indicator of viruscell fusion in numerous systems (Düzgünes et al., 1992; Gilbert et al., 1990: Hoekstra, 1990; Pedroso de Lima et al., 1991: Puri et al., 1993; Ramalho-Santos et al., 1993).

The fusion activity of R18-labeled Sendai virus towards erythrocytes/erythrocyte ghosts is shown in Fig. 1. Two different experimental approaches were used to quantify viral fusion activity. In one set of experiments the virus was allowed to bind to erythrocytes/erythrocyte ghosts for $15 \mathrm{~min}$ on ice before initiation of the 


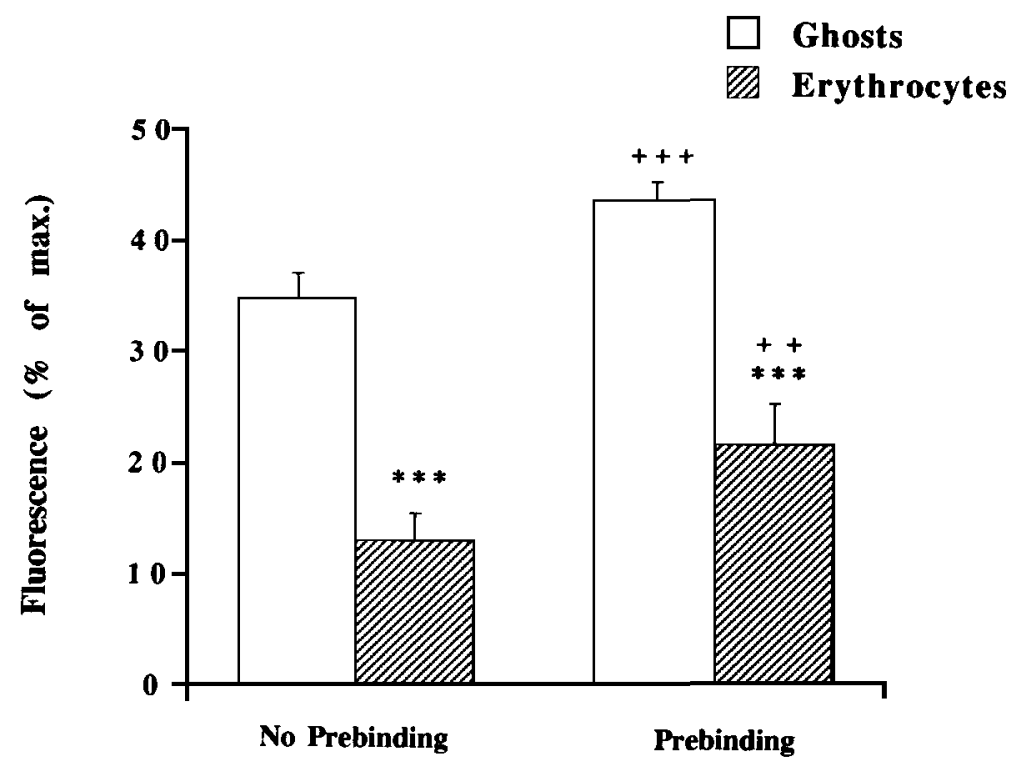

Fig. 1. Sendai virus fusion activity towards erythrocytes and erythrocyte ghosts. Sendai virus $\left(5 \mu \mathrm{g}\right.$ viral protein $/ \mathrm{ml}$ ) was added to $1 \times 10^{8}$ erythrocyte ghosts (open bars) or erythrocytes (striped bars) in a final volume of $2 \mathrm{ml}$ at $37^{\circ} \mathrm{C}$. The extent of $\mathrm{R} 18$ fluorescence dequenching was measured after $10 \mathrm{~min}$ incubation at $\mathrm{pH} 7.4$, with or without prebinding of the virus to the cells. In the case of viral prebinding, the virus was pre-incubated with erythrocytes/erythrocyte ghosts for $15 \mathrm{~min}$ at neutral $\mathrm{pH}$ on ice. In the absence of viral prebinding, fusion was initiated by rapid injection of the virus to the erythrocytes/erythrocyte ghosts suspension. Values represent means of 5 experiments \pm standard deviation. $++P<0.01 ;+++P<0.001$, signifcantly different compared to no prebinding conditions. ${ }^{* * *} P<0.001$, significantly different compared to ghosts under the same conditions.

fusion reaction at neutral $\mathrm{pH}$ (experiments with virus-target membrane prebinding). In the other set of experiments, fusion was initiated by rapid injection of the virus to the erythrocytes/erythrocyte ghosts (experiments without virus-target membrane prebinding). When the virions were prebound to the target membranes the extent of fusion was higher (Fig. 1), as would be expected, since with virus prebinding on ice, fusion can be triggered more rapidly. On the other hand, when virions are added directly to target membranes, they must bind to erythrocytes or erythrocyte ghosts before membrane merging can take place. However, since this process corresponds to the biological fusion reaction, further experiments were carried out without viral prebinding to target membranes.

Resealed erythrocyte membranes (ghosts) are valuable tools in the study of biological membrane functions, since after hypotonic lysis and subsequent resealing, the membrane regains many of its natural characteristics (Lieber and Steck, 1982a; 1982b; Wood and Passow, 1981). However, Sendai virus does not exhibit the same fusion behavior towards erythrocytes and erythrocyte ghosts. Indeed, Sendai virus fuses much more extensively with erythrocyte ghosts than with erythrocytes (Fig. 1). 
Table 1. Binding of Sendai Virus to Erythrocytes and Erythrocyte Ghosts

\begin{tabular}{lcc}
\hline & \multicolumn{2}{c}{ Binding $(\%)$} \\
\cline { 2 - 3 } Cells & Ghosts & Erythrocytes \\
\hline Binding $(\%)$ & $60.72 \pm 2.08$ & $59.41 \pm 0.38$ \\
\hline Sendai virus $(5 \mu \mathrm{g}$ viral protein $/ \mathrm{ml})$ & was added to $1 \times 10^{8}$ \\
erythrocytes/erythrocyte ghosts in a final volume of $2 \mathrm{ml}$ at \\
$0^{\circ} \mathrm{C}$ and pH 7.4 . Following a 30 min incubation, the mixture \\
was centrifuged and virus-target membrane binding was \\
quantified after triton X-100 addiction, to both pellet and \\
supernatant, as described in Materials and Methods. Values \\
represent means of 2-5 experiments \pm standard deviation.
\end{tabular}

This difference is probably related to differences in the membrane packing of both targets. During the preparation of erythrocyte ghosts, in the step of hypotonic hemolysis, a single large fenestration is opened in the membrane by the imposed osmotic stress (Lieber and Steck, 1982a; 1982b). The hole is a breach in membrane continuity normally ascribed to the bilayer, to the membrane proteins and, in particular, to the reticulum of spectrin and actin that covers the cytoplasmatic surface (Lieber and Steck, 1982b). The changes that occur in the erythrocyte membrane during ghost formation may not be completely reversed by the resealing procedure, thus affecting bilayer packing. Our supposition is in agreement with other studies where it was observed that the acyl chain mobility of the outer leaflet of ghost membranes is higher than that of erythrocytes (Herrmann et al., 1993). Increased acyl chain mobility of membrane phospholipids and hydrophobicity of the membrane surface may facilitate the process of membrane fusion.

These results indicate that extrapolation of the characteristics of viral fusion activity towards erythrocyte ghosts should be made with caution. Membrane organization and dynamics or some membrane component appear to be significant factors in Sendai virus-induced fusion. Interestingly Sendai virus binding was virtually the same towards both erythrocytes/erythrocyte ghosts (Table I), suggesting that membrane surface characteristics (at least in what concerns sialic acid residues) is not affected by the preparation of erythrocyte ghosts.

\section{Effect of Proteinase K Pretreatment of Erythrocytes and Erythrocyte Ghosts on Sendai Virus Fusion Activity}

In order to determine whether the differences between erythrocyte ghosts and erythrocytes as targets for Sendai virus concerned surface proteins, both target membranes were treated with proteinase $\mathrm{K}$. This proteolytic treatment did not promote significant differences in the binding capacity of Sendai virus towards erythrocyte ghosts and erythrocytes (data not shown). However, inhibition of the fusion process of Sendai virus with both target membranes was observed (Fig. 2).

These results indicate the existence of membrane components cleaved by proteinase $\mathrm{K}$, which may facilitate the formation of a fusogenic complex between the virus and the target membrane. It is possible that the proteins cleaved by proteinase 


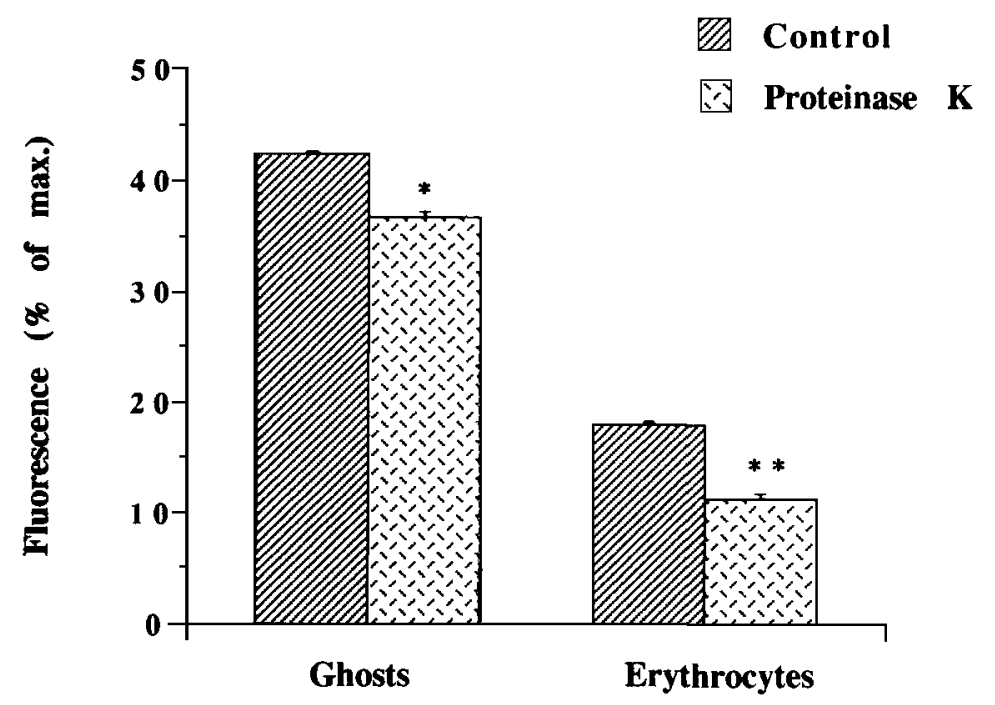

Fig. 2. Effect of Proteinase K pretreatment of erythrocytes and erythrocyte ghosts on Sendai virus fusion activity. Sendai virus $(5 \mu \mathrm{g}$ viral protein $/ \mathrm{ml})$ was added to $1 \times 10^{8}$ control (striped bars) or proteinase $\mathrm{K}$ treated (threaded bars) erythrocyte ghosts/erythrocytes in a final volume of $2 \mathrm{ml}$ at $37^{\circ} \mathrm{C}$. The extent of $\mathrm{R} 18$ fluorescence dequenching was measured after $10 \mathrm{~min}$ incubation at $\mathrm{pH} 7.4$, with viral prebinding to the target cells. In prebinding, the virus was pre-incubated with erythrocytes/erythrocyte ghosts for $15 \mathrm{~min}$ at neutral $\mathrm{pH}$ on ice. Values represent means of $2-5$ experiments \pm standard deviation. ${ }^{*} P<0.05 ;{ }^{* *} P<0.01$, significantly different compared to control conditions.

$\mathrm{K}$ are involved in the establishment of a correct positioning of the virus after binding and before fusion.

\section{Effect of Neuraminidase Pretreatment of Erythrocytes and Erythrocyte Ghosts on Sendai Virus Fusion Activity}

The initial event in the entry of a lipid-enveloped virus into host cells is viral attachment to specific receptors. Sialic acid residues present on membrane glycoproteins or glycolipids at the cell surface have been considered to be the primary receptors for Sendai (Markwell et al., 1984; White, 1990) and influenza viruses (Bengelson et al., 1982; Pedroso de Lima et al., 1995; Paulson et al., 1986). The presence of these residues has also been shown to modulate influenza virus fusion activity (Pedroso de Lima et al., 1991).

However, in contrast to what has been obtained with influenza virus (Stegmann et al., 1986), and that we have confirmed (data not shown), we have not observed any significant effect of neuraminidase pretreatment of target membranes on Sendai virus fusion with both erythrocytes and erythrocyte ghosts (Fig. 3). Interestingly, virus-target membrane binding towards both types of target membranes was significantly reduced following pretreatment with neuraminidase (Table II). These results confirm the importance of sialic acid residues as viral receptors for Sendai virus. 


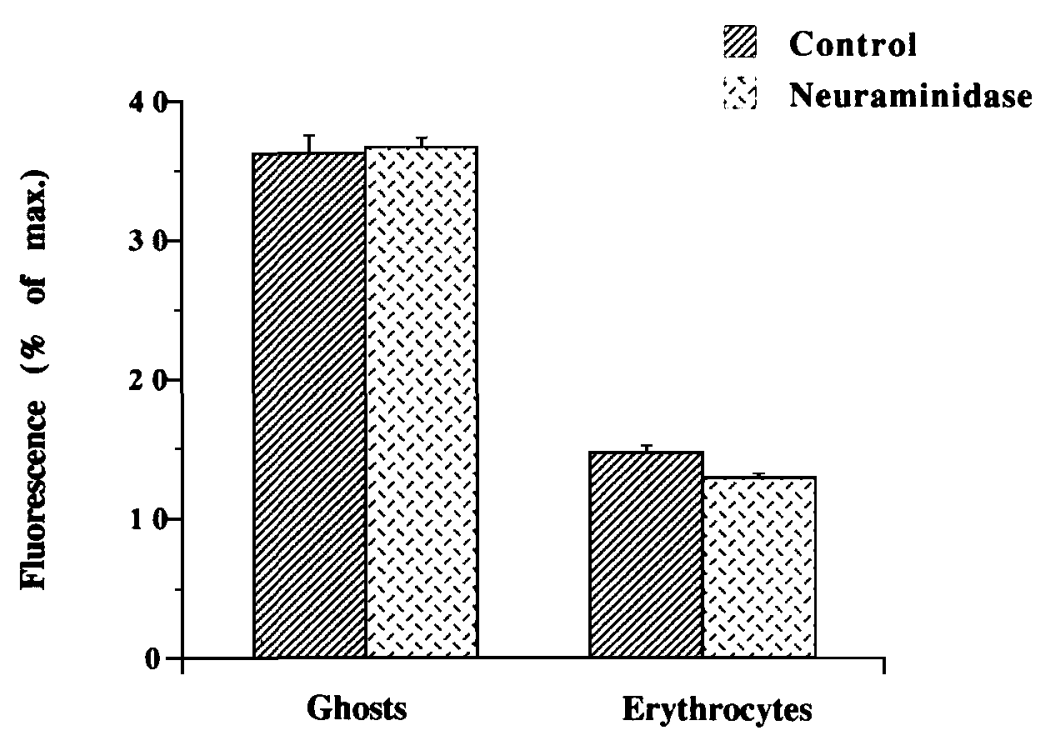

Fig. 3. Effect of neuraminidase pretreatment of erythrocytes and erythrocyte ghosts on Sendai virus fusion activity. Sendai virus $(5 \mu \mathrm{g}$ viral protein $/ \mathrm{ml})$ was added to $1 \times 10^{8}$ control (striped bars) or neuraminidase-treated (threaded bars) erythrocyte ghosts/erythrocytes in a final volume of $2 \mathrm{ml}$ at $37^{\circ} \mathrm{C}$. The extent of $\mathrm{R} 18$ fluorescence dequenching was measured after $10 \mathrm{~min}$ incubation at $\mathrm{pH} 7.4$, without prebinding of the virus to the cells. Fusion was initiated by rapid injection of the virus to the cell/ghost suspension. Values represent means of 2-5 experiments \pm standard deviation.

However, under our experimental conditions a decrease in viral binding does not affect the extent of the fusion reaction itself. It should be noted that recent studies have shown that binding of Sendai virus is more sensitive than fusion to the presence/absence of sialic acid residues on target membranes (Wybenga et al., 1996).

It is possible that the neuraminidase pretreatment affects target membranes in a way which facilitates membrane merging. In fact, Yamaguchi et al. (1993) observed that erythrocyte membranes in which sialic acid had been removed by neuraminidase become more fragile with respect to their susceptibility to undergo hemolysis under osmotic stress as compared to intact cells. Sialic acid residues may, as well, play a barrier between the virus and the target membrane, and thus the removal of these residues may facilitate membrane fusion. These effects could compensate for the lower binding of Sendai virus towards both types of target membranes.

In conclusion, our results clearly show that erythrocytes and erythrocyte ghosts are not equivalent as target membranes for the study of Sendai virus fusion activity, probably due to differences in bilayer packing. Although target membrane proteins may play a role in Sendai virus-induced membrane fusion, it seems clear that target membrane sialic acid residues (the biological receptors for the virus) do not have a significant effect in directly modulating membrane merging, in sharp contrast to what happens with the fusion event promoted by influenza virus. 
Table 2. Effect of Neuraminidase Pretreatment on Sendai Virus Binding Towards Erythrocytes and Erythrocyte Ghosts

\begin{tabular}{|c|c|c|}
\hline \multirow[b]{2}{*}{ Cells } & \multicolumn{2}{|c|}{ Binding ( $\%$ control) } \\
\hline & Ghosts & Erythrocytes \\
\hline NA-treated & $43.89 \pm 3.35^{* *}$ & $29.33 \pm 0.65^{* *}$ \\
\hline \multicolumn{3}{|c|}{$\begin{array}{l}\text { Sendai virus ( } 5 \mu \mathrm{g} \text { viral protein } / \mathrm{ml}) \text { was added to } 1 \times 10^{8} \\
\text { control or neuraminidase-treated erythrocytes/erythrocyte } \\
\text { ghosts in a final volume of } 2 \mathrm{ml} \text { at } 0^{\circ} \mathrm{C} \text { and } \mathrm{pH} 7.4 \text {. Follow- } \\
\text { ing a } 30 \mathrm{~min} \text { incubation, the mixture was centrifuged and } \\
\text { virus-target membrane binding was quantified after triton } \\
\mathrm{X}-100 \text { addition, to both pellet and supernatant, as described } \\
\text { in Materials and Methods. Values represent means of } 2-5 \\
\text { experiments } \pm \text { standard deviation }{ }^{* *} P<0.01 \text {; }{ }^{* *} P<0.001 \text {, } \\
\text { significantly different compared to control conditions. }\end{array}$} \\
\hline
\end{tabular}

\section{ACKNOWLEDGMENT}

This work was supported by JNICT, Portugal.

\section{REFERENCES}

Bengelson, L. D., et al. (1982) Eur. J. Biochem. 128:467-474.

Düzgünes, N., et al. (1992) J. Gen. Virol. 73:27-37.

Gilbert, M. J., Mason, D., and White, J. M. (1990) J. Virol. 64:5106-5113.

Haywood, A. M. and Boyer, B. P. (1982) Biochemistry 21:6041-6046.

Herrmann, A., Clague, M. J., and Blumenthal, R. (1993) Membr. Biochem. 10:3-15.

Hoekstra, D. (1990) J. Bioenerg. Biomemb. 22:121-155.

Hoekstra, D. and Klappe, K. (1986) J. Virol. 58:87-95.

Hoekstra, D. and Kok, J. W. (1989) Biosci. Rep. 9:273-305.

Hoekstra, D., de Boer, T., Klappe, K., and Wilschut, J. (1984) Biochemistry 23:5675-5681.

Hoekstra, D., Klappe, K., de Boer, T., and Wilschut, J. (1985) Biochemistry 24:4739-4745.

Lieber, M. R. and Steck, T. L. (1982a) J. Biol. Chem. 257:11651-11659.

Lieber, M. R. and Steck, T. L. (1982b) J. Biol. Chem. 257:11660-11666.

Maeda, T., Asano, A., Ohki, Y., Okada, Y:; and Ohnishi, S. I. (1975) Biochemistry 14:3736-374l.

Markwell, M. A., Fedman, P., and Svennerholm, L. (1984) Biochim. Biophys. Acta 775:7-16.

Novick, S. L. and Hoekstra, D. (1988) Proc. Natl. Acad. Sci. USA 85:7433-7437.

Paulson, J. C., Rogers, G. N., Murayama, J. I., Sze, G., and Martin, E. (1986) in: Virus Attachment and Entry into Cells (Crowell, R. L. and Lonberg-Holm, K., Eds.) American Society for Microbiology, Washington, DC. pp. 144-151.

Pedroso de Lima, M. C., Nir, S., Flasher, D., Klappe, K., Hoekstra, D., and Düzgünes, N. (1991) Biochim. Biophys. Acta 1070:446-454.

Pedroso de Lima, M. C., Ramalho-Santos, J., Flasher, D., Slepushkin, V. A., Nir, S., and Düzgünes, N. (1995) Biochim. Biophys. Acta 1236:323-330.

Pedroso de Lima, M. C., Ramalho-Santos, J., Martins, M. F., Carvalho, A. P., Bairos, V. A., and Nir, S. (1992) Eur. J. Biochem. 205:181-186.

Puri, A., Clague, M. J., Schoch, C., and Blumenthal, R. (1993) Methods Enzymol. 220:277-287.

Ramalho-Santos, J., Nir, S., Düzgünes, N., Pato de Carvalho, A., and Pedroso de Lima, M. C. (1993) Biochemistry 32:2771-2779.

Schwoch, G. and Passow, H. (1973) Mol. Cell. Biochem. 2:197-218. 
Steck, T. L. and Kant, J. A. (1974) Methods Enzymol. 31:172-180.

Stegmann, T., Doms, R. W., and Helenius, A. (1989) Ann. Rev. Biophys. Biophys. Chem. 18:187-211.

Stegmann, T., Hoekstra, D., Scherphof, G., and Willschut, J. (1986) J. Biol. Chem. 261:10966-10969.

White, J. M. (1990) Ann. Rev. Physiol. 52:675-697.

Wood, P. G. and Passow, H. (1981) in: Techniques in Cellular Physiology (Baker, P. F., Eds.), Vol. P1/ 4 (P112), Elsevier/North-Holland, County Clare, Ireland. pp. 1-43.

Wybenga, L. E. (1996) Biochemistry 35:9513-9518.

Yamaguchi, T., Matsumoto, M., and Kimono, E. (1993) J. Biochem. 114:576-581. 